\title{
Demoralization of Government Bureaucratic Corruption in East Kutai District Head Ismunandar
}

\author{
Rita Kalalinggi ${ }^{1}$, \\ ${ }^{1}$ Governance of Science, Faculty of Social and Politic, Universitas Mulawarman, Indonesia. \\ Corresponding Author: ritakalalinggi4@gmail.com
}

\section{Article Info}

Keyword:

Bureaucracy;

Demoralization;

Corruption;

East Kutai District.

Kata Kunci:

Birokrasi;

Demoralisasi;

Korupsi;

Kutai Timur.

\begin{abstract}
This study uses the literature review method through journals and supporting reports that are related to this study and explained descriptively through data obtained from journals or reports. The findings generated in this study are corruption cases involving regional heads in East Kutai and their ranks are inseparable from the existence of oligarchic politics, all of these cannot be separated from the compatibility of a project. Cases like this are rife in bureaucratic and political elites who sometimes use family connection mechanisms. According to records from the Corruption Eradication Commission (KPK) from 2015 to 2018 in terms of cases and the number of suspects continues to increase. In 2018, the KPK handled 57 cases with 261 suspects and a total loss of Rp385 billion. Where the average cases handled by the KPK per month are five cases with an estimated value of Rp6.6 billion. Corruption acts carried out by the KPK mostly function as chairmen or members of the Regional House of Representatives (DPRD) with a total of 103 suspects. Acts of corruption are often carried out by political elites in the DPR as well as in law enforcement agencies. However, the most vulnerable to corruption is the village. the most vulnerable sector in 2018 is the village budget. There were 96 cases of corruption related to the village budget involving 133 suspects with state losses of Rp. 37.2 billion. Meanwhile, the sector that caused the highest state loss was the banking sector amounting to Rp2,100 billion (16 cases).
\end{abstract}

Abstrak: Penelitian ini menggunakan metode literature review melalui jurnal dan laporan pendukung yang terkait dengan penelitian ini dan dijelaskan secara deskriptif melalui data yang diperoleh dari jurnal atau laporan. Temuan yang dihasilkan dalam penelitian ini adalah kasus korupsi yang melibatkan kepala daerah di Kutai Timur dan perangkatnya yang tidak dapat dipisahkan dari keberadaan politik oligarkis, semua ini tidak dapat dipisahkan dari kompatibilitas suatu proyek. Kasus-kasus seperti ini banyak terjadi di kalangan elit birokrasi dan politik yang terkadang menggunakan mekanisme koneksi keluarga. menurut catatan Komisi Pemberantasan Korupsi (KPK) dari 2015 hingga 2018 dalam hal kasus dan jumlah tersangka terus meningkat. Pada 2018, KPK menangani 57 kasus dengan 261 tersangka dan total kerugian Rp385 miliar. Dimana rata-rata kasus yang ditangani oleh KPK per bulan adalah lima kasus dengan estimasi nilai Rp6,6 miliar. Tindakan korupsi yang dilakukan oleh KPK sebagian besar berfungsi sebagai ketua atau anggota Dewan Perwakilan Rakyat Daerah (DPRD) dengan total 103 tersangka. Tindakan korupsi sering dilakukan oleh elit politik di DPR maupun di lembaga penegak hukum. Namun, yang paling rentan terhadap korupsi adalah desa. sektor yang paling rentan pada 2018 adalah anggaran desa. Ada 96 kasus korupsi terkait dengan anggaran desa yang melibatkan 133 tersangka dengan kerugian negara sebesar Rp. 37,2 miliar. Sementara itu, sektor yang menyebabkan kerugian negara tertinggi adalah sektor perbankan sebesar Rp2.100 miliar (16 kasus).

Article History: Received: 2020-10-21, Revised: 2020-10-26, Accepted: 2020-10-30 


\section{INTRODUCTION}

Government as one of the important elements of the state has a determinant position in relation to the administration of government both outward and inward because of its strategic position, the existence of the state and in particular the state government is very much determined by the success of the government and the government in organizing the government in the framework of achieving goals country. On this basis, without a government, the country's goals will not be achieved. If this condition occurs, a large loss will be borne by the general public, given that one of the goals of forming a government is to increase the welfare of the community. More important than that is that the existence of one country in relation to other countries (Anggraeni, 2014).

The progress of a country is largely determined by the ability and success in carrying out development. The success of development is mainly determined by human resource factors, namely humans as the most dominant actor. Indonesia is one of the richest countries in Asia in terms of the diversity of its natural resource wealth. But ironically, when compared to other countries in Asia, it is not a rich country but even a poor country. One of the reasons is the low quality of human resources. This quality is related to the moral quality and personality. Moral fragility and the low level of honesty of the state administration apparatus causes corruption (Nugroho, 2013).

Corruption in Indonesia today is a very dangerous social pathology that threatens all aspects of social life as a nation and state. Corruption cases in Indonesia continue to increase. Corruption cases that have been decided by the Corruption Case Collection (KPK) from 20152018 are 803 cases. This number increased considerably compared to the previous year. Research by the University of Gadjah Mada revealed that 803 cases ensnared 967 defendants in corruption. If calculated from 2001 to 2015, corruption cases that have been decided by the Supreme Court at the cassation level and reconsideration reached 2,321 cases. On the other hand, the amount corrupt those sentenced in that period reached 3,109. This number increased dramatically when compared with data in 2001-2009. At that time, there were 549 corruption cases with 831 convicts. Data Transparency International Indonesia TII said the score of 37 points was obtained through a survey conducted in 10 cities in Indonesia. Although up one point, globally, Indonesia ranks 90th out of 176 countries measured in the world. Other than that,Corruption cases handled by the Corruption Eradication Commission (KPK) are mostly (77\%) corruption cases related to the procurement of goods and services (Badjuri, 2011).

Corruption like this occurs at all levels of government, not only at the center but also in the regions. In fact, since the enactment of regional autonomy based on Law Number 22 Year 1999 concerning Regional Government in 2001 there has been a tendency for corruption in Regional Government which has sharply increased (Rahman, 2011). Bureaucratic corruption as a designed behavior that is actually a behavior that deviates from the expected norms that are intentionally done to get material rewards or other rewards. Bureaucratic corruption occurs in a social context, especially in organizations (public), which are a source of authority or authority (discretion) of civil servants. Corruption in the public bureaucracy is a complex phenomenon that is driven by various factors that are interrelated to one another; therefore corruption is referred to as 'multi-faceted social problems'. Various factors that cause corruption basically can be the cause is structural (Slater \& Simmons, 2010).

Structural factors are supervisory factors. The more effective the surveillance system is, the less likely it is that there will be opportunities for corruption and collusion. Conversely, if corruption and collusion are widely practiced, there is something wrong with the surveillance system. As happened in the bureaucracy in Indonesia, even though functional oversight institutions have been built in layers, these institutions are generally unable to carry out their functions properly. Weak supervision occurs because of the influence of the dominant position of the government bureaucracy as the main source of goods, services and employment and as a regulator of economic activity; and the dominance of the state which dwarfs other forces in society. Weak citizens will offer bribes in the hope that they can change the behavior of bureaucrats who keep their distance closer to him and become his 'patron' (Wakhid, 2011). 
Clean governance is now a fundamental prerequisite for the survival of a country in its efforts to realize bureaucratic reform. The era of economic liberalization marked by a high level of competition between countries requires the readiness of resources and institutional and legal instruments that support a healthy market. Therefore, the eradication of corruption becomes a necessity if a country wants to survive and be taken into account in the arena of international political economy. Furthermore, this paper will discuss what factors cause bureaucratic corruption and the impact of corruption on the country. So that in this study raises a problem formulation that is how to divert the transition of corruption in Indonesia, especially in the area of East Kutai? who are the actors involved?

\section{RESEARCH METHOD}

In terms of the procedures and patterns adopted by researchers, this study is included in the type of qualitative research. Bogdan and Taylor as quoted by Moleong, (2012) define qualitative methodology as a research procedure that produces descriptive data in the form of written or oral words from people and observable behavior. So qualitative research is research that produces conclusions about data that describe in detail, not produce data in the form of numbers. In line with the above definition, Kirk and Miller in Moleong, define qualitative research as a particular tradition in social science that is fundamentally dependent from observations in humans both in the region and in terminology.

In other words it can be explained that qualitative research is a type of research that relies on observations, interviews and documentation on research objects so that data are produced that describe in detail and in full about the object of research. The research pattern used in this study is a descriptive pattern. This pattern means research that "will only describe the state of the object or problem and is not intended to draw or draw conclusions that are generally accepted". According to research theory, there are two characteristics of descriptive patterns, namely exploratory and developmental. However, in this study using a descriptive exploratory pattern that is, "aims to describe the state or status of the phenomenon". So it can be concluded that this study uses explorative descriptive patterns, namely research patterns that describe in detail or in full the state or status of the phenomenon of the object of research and do not seek conclusions that apply in general. The conclusion drawn is a picture that occurs on the object of research.

\section{Demoralizing Bureaucracy}

The most destructive thing for the development of democracy and good governance in this country is political corruption. The most dangerous of this type of corruption is not individual corruption committed by politicians, but rather the manipulation of state financial resources in the name of government policy for the benefit of political party networks. state ministries that are biased in favor of the interests of their own party networks. With such a tendency, ministers from political parties tend to damage the morals and principles of true public service (Suherry, 2017).

In some ministries, projects tend to be directed towards their own constituent network. Even social assistance interventions are no longer based on the principle of advancing public welfare and that the poor are impartially maintained by the state. Various aid designs and recipients of social assistance are tailored to the party network and political targets (Suherry, 2017).

In various ministries, career officials have only two choices: support their ministers' political targets or be prepared to accept the reality that their careers are hampered. The collapse of the merit system led to bureaucracy being led by petty officials. Bureaucratic demoralization is a general picture that is developing at this time. In current practice, many ministers do not understand the code of ethics and professional commitment. Bureaucratic policies and services that are supposed to be impersonal and impartial are replaced by partisan attitudes that tend to serve personal and partial interests (Baswir, 2002).

According to Baswir, (2002) Corruption cases are very diverse in forms, as well as slow service, and are followed by convoluted procedures or better known as the red-tape effect 
signifying the poor image of the government bureaucracy. Cases of corruption are always the main focus and become the material of media coverage, especially cases involving state officials. Corruption has spread from the center to the regions, from the executive, the legislature, to the judiciary.

Hadiz, Vedi R (2010) is referred to as local strongmen and predatory. The emergence of local bosses, local strongmen and predators who accompanied the process of democratization became an endemic phenomenon today. The presence of local bosses and local strongmen developed along with the transfer of governmental authority to the regions (decentralization). In the era of centralization this phenomenon was rarely found because government management was managed centrally. This decentralization was exploited by some local political elites to build political and economic oligarchies that gave rise to strong people at the local level (Hadiz, 2004).

Over time, the democratization process increasingly shows pre-democratic democracy characterized by the behavior of corrupt practices and abuse of power by officials that spread to all levels of government. The increasingly wild democratization process has provided opportunities for political actors to master the stage of democracy in various political forces that are spread from the center to the regions and make the people the object of mobilization and a means of legitimacy to exercise control over political and economic power (Pratama et al., 2019).

The democratic transition and prolonged consolidation of democracy, changes in the institutions of power and increasingly liberal democratic institutions, in the name of democratization actually made the political system give birth to oligarchic power (Winters, 2013). The owners of capital and state robbers (predator), become holders of power and illegally share various concessions and privileges to the political and economic cronies on a massive and systemic scale, from the center to the regions and cover various strategic sectors. The emergence of several regional officials after Suharto who has a background in businessmen who controlled the stage of democracy, as a logical consequence of the high cost of democracy (cost democracy) (Slater \& Simmons, 2010). It has become a political conviction; only candidates with large capital have the chance to win the election contest. This does not mean that the power of money is the only determinant of victory in regional election contestation. In the era of the capitalization of the elections, money has become a myth of pragmatism for some of the public that the regional head candidates are exhibiting. a mind pragmatism and a structured public perception that Pilkada is the arena of money distribution (vote politics), buying and selling votes and various modes to attract sympathy for the people. (Aspinall, 2015)

Regarding the high cost of local elections, candidates try to find political funds in various modes, including the mode of making natural resources a transactional basis by actors related to natural resource management licenses, such as mining, oil palm, forestry, and other permits (Lay, 2012). as a political strategy in the elections. The regional head selection (Pilkada) has been reduced to a transaction pragmatic arena of political actors and between political actors and the masses. Expensive political costs make the party of democracy an arena of exchange of resources owned by political actors. The elected regional authorities will use power, regulation, policy, and protection of power will exchange power resources to entrepreneurs who have capital power (Ford \& Pepinsky, 2014). Therefore, it is not strange if the local election is only giving birth to regional rulers who perpetuate oligarchic politics at the local level and encourage the widespread practice of shadow state or informal economy in regional government (Tahir et al., 2015).

\section{The Indonesian Corruption Case}

\section{RESULT AND DICUSSION}

Seeing a reality is no longer a secret that corruption in Indonesia has penetrated to all layers of state institutions and involved all state apparatuses from the top to the bottom. Corruption in the public bureaucracy is a complex phenomenon that is driven by various factors that are interrelated to one another, therefore corruption is referred to as' multi-faceted social 
problems'. From various factors causing corruption basically can be grouped into cultural, structural, and individual causes.

One cultural factor that is widely used to understand cases of corruption in developing countries is the local political culture factor. The bureaucracy in Indonesia shows the mixed characteristics of the feudal bureaucracy which is a feature of royal government and rational bureaucracy that was introduced to Indonesia by the Dutch colonial government. Bureaucracy which is a mixture of elements of the western bureaucracy and elements that originate from royal political culture or patrimonial bureaucracy.

A leader in a patrimonial type of bureaucracy has a tendency to consider political power as part of private property, so that in its use many discretions are made. Understanding or perception of leaders to power will affect the leadership behavior. This patrimonial culture which considers power as private property is suitable to describe the feudal political culture of the kingdom in Indonesia, especially Java. The understanding and perception of Javanese kings who saw power as their own influenced their leadership. Other cultural factors that encourage corruption are the tradition of giving gifts to government officials and the importance of family ties in the culture of developing country societies.

Reports of gratuities throughout 2018 namely 2,349 reports. Where the most executive reporting is 1,476 reports to the ministry (683 reports). Then, in the second position, 717 reports were occupied by BUMN or BUMD. Gratification according to the Law is a gift in a broad sense, which includes the provision of money, goods, rebates (discounts), commissions, loans without interest, travel tickets, lodging facilities, travel tours, free medical treatment, and other facilities.

In Indonesia, the obligation of a person is first to pay attention to his closest sibling, then his breed or ethnicity. So that a brother who goes to an official to ask for special treatment is difficult to refuse. Rejection can be interpreted as a denial of traditional obligations. But following the request means denying the norms of formal law that apply, namely Western law. So there is always a conflict of values, namely between consideration of family interests or public interests Another factor closely related to corruption is the structural factor, namely the supervision factor. The more effective the surveillance system is, the less likely it is that there will be opportunities for corruption and collusion. Conversely, if corruption and collusion are widely practiced, there is something wrong with the surveillance system.

As happened in the bureaucracy in Indonesia, even though functional oversight institutions have been built in layers, these institutions are generally unable to carry out their functions properly. In fact, outside the internal functional oversight institutions there are external oversight institutions, such as the Financial Oversight Board and the House of Representatives. The problem is because the government's dominance over external oversight institutions is so strong that these institutions have become powerless. One of the institutions for overseeing and prosecuting corruption cases in Indonesia is conducted by the Corruption Eradication Commission (KPK).

Enforcement of corruption cases handled by the Corruption Eradication Commission (KPK) from 2015 to 2018 in terms of cases and the number of suspects continues to increase. In 2018, the KPK handled 57 cases with 261 suspects and a total loss of Rp385 billion. Where the average cases handled by the KPK per month are five cases with an estimated value of Rp6.6 billion. The corruption act carried out by the KPK mostly served as chairman or member of the Regional People's Representative Council (DPRD) with a total of 103 suspects.

The number of corruption committed by the House of Representatives (DPR) and the Regional House of Representatives (DPRD) from 2004 to 2018 was 67 cases. In 2005 until 2007 there were no criminal acts of corruption. However, in 2016 the criminal act of corruption by the DPR and DPRD jumped to 15 cases. One of the most corrupt parties is the Golkar party. This shows how corruption took place again in 2016, meaning that the lack of supervision and improper enforcement has brought corruption to the surface. Corruption can indeed not be stopped, but if there is a punishment that makes a deterrent effect to the political elite and the ruling bureaucracy, then the act of denying the effect of the act of crops can be suppressed and minimally optimized. 
Based on the data above figure 1, that the corruption cases handled by the KPK, according to the Katadata database, (2019) corruption cases handled from 2004-2019 according to the type of case, namely bribery in the case of 661 cases; procurement of goods and services consisting of 205 cases; budget abuse consisted of 48 cases, money laundering consisted of 34 cases; there were 26 cases of levies; licensing there were 23 cases; blocking the KPK case there were 10 cases

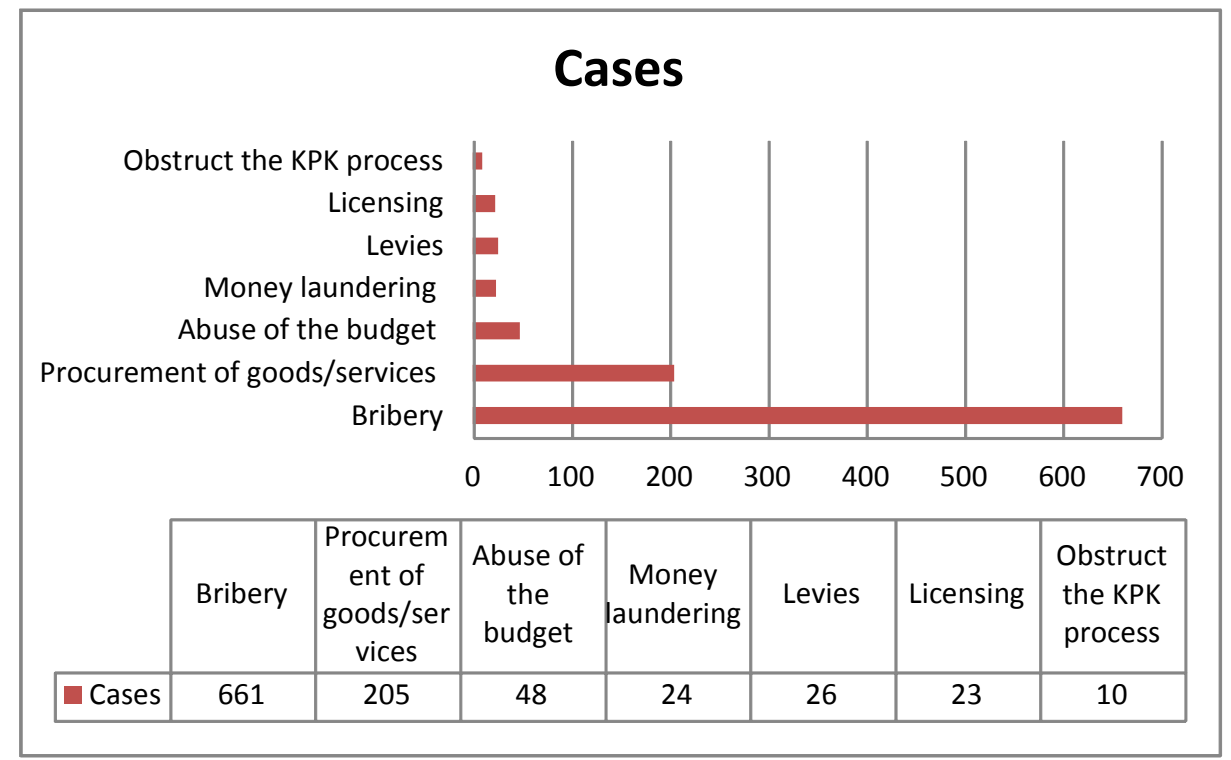

Figure.1 corruption acts handled by the KPK according to the types of cases from 2004- June 2019

Source: Katadata, (2019).

Figure.2 Golkar was the most corrupt party in the period 2014 to 2019, as many as 8 politicians were entangled in corruption cases, according to the Indonesia Corruption Watch. Even so, it should be noted, the second-largest parliamentary ruling Golkar compared to the PDIP with 91 seats in 2014. Meanwhile, PDIP cadres who got entangled by rasuah as many as 2 people. During this period, 109 cadres of the Banteng party occupied the parliamentary seats in Senayan.

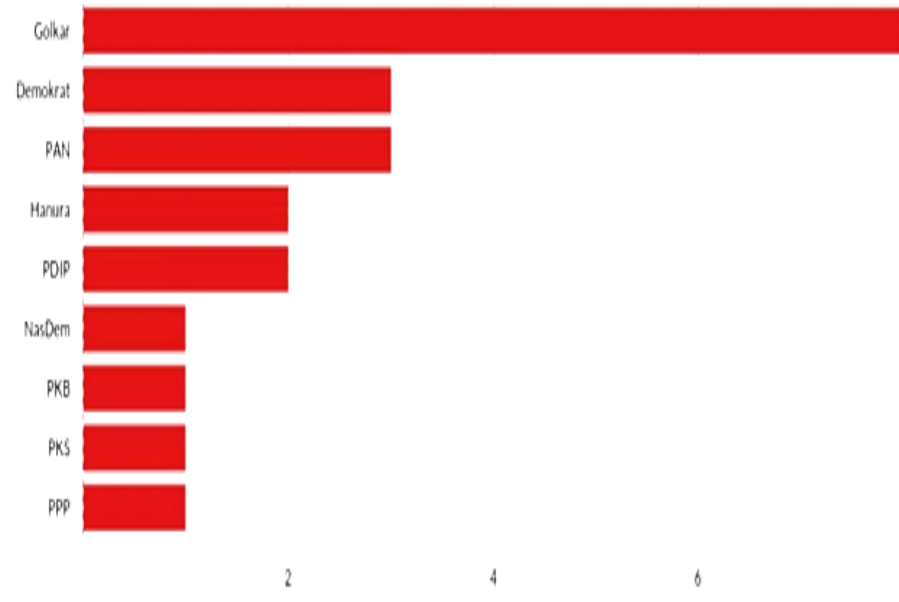

Figure.2 Corruption suspects for the 2014-2019 DPR members according to the party Source: ICW, (2019). 


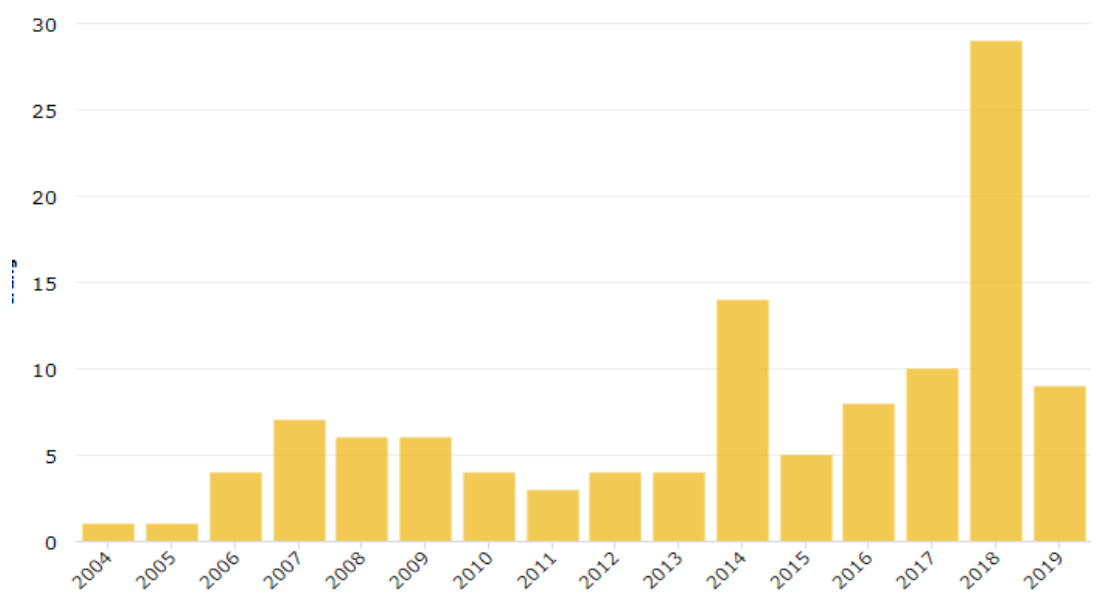

Figure.3 Number of regional heads captured by the KPK Source: KPK, (2019).

Figure. 3 The Corruption Eradication Commission (KPK) noted that 114 regional heads were caught in Rasuah cases from 2004 to 2019. In detail, 73 people or $64 \%$ were regents, 25 people or $24 \%$ were mayors, and 16 people or $22 \%$ were governors. In the last 15 years, the highest number of regional heads caught in corruption was in 2018. Two years ago, the KPK arrested 29 regional heads. The details, two governors, 22 regents, and five mayors.

District government
village government
City government
ministry
BUMN
provincial
government
State agencies /
institutions
DPRD
BUMD
law enforcer*

Figure.4 Enforcement of corruption cases based on 2019 law enforcement institutions. Source: ICW, (2020).

Figure.4 Indonesia Corruption Watch (ICW) ranked the top 10 institutions with the most findings of corruption cases in 2019. District governments are the most institutions with 95 findings of corruption cases. Corruption in this institution has cost the state up to Rp. 6.1 trillion. The village government followed with 48 case findings. The state lost around Rp. 32.7 billion due to corruption by this institution.

Several other agencies are also involved, such as city governments, ministries, State, and Regional Owned Enterprises. Even law enforcers have not escaped the findings of corruption cases. The law enforcers referred to are the prosecutor's office, police, and courts. There were at least six findings of corruption cases carried out by law enforcement during 2019.

\section{Corruption Case in East Kutai, East Kalimantan}

The KPK officially named the East Kutai Regent (Kutim) Ismunandar and his wife Encek UR Firganih as suspects over alleged bribery cases related to a number of infrastructure 
projects in Kutim. Determination of Ismunandar and his wife was delivered directly by KPK Deputy Chairman Nawawi Pomolango in a press conference at the KPK Red House. Kutai Timur Aswandini.

Meanwhile, two other suspects named as bribe suspects are a contractor named Aditya Maharani and a project partner named Deky Aryanto. The evidence that the KPK has now secured is in the form of cash as much as Rp 170 million, several bank account books with a total balance of $\mathrm{Rp} 4.8$ billion. The bribery suspects are suspected of violating Article 12 Paragraph (1) letter B or Article 11 of Law Number 31 of 1999 as amended by Law Number 20 of 2001 concerning Eradication of Corruption in conjunction with Article 55 Paragraph (1) of the KUHP in conjunction with Article 65 Paragraph (1) of the Criminal Code.

Meanwhile, bribery suspects are suspected of violating Article 5 Paragraph (1) letter A or B or Article 13 of Law Number 31 of 1999 as amended by Law Number 20 of 2001 concerning Eradication of Corruption in conjunction with Article 55 Paragraph (1) KUHP juncto Article 64 Paragraph (1) KUHP.East Kutai Regent Ismunandar in the arrest operation carried out by the KPK is a portrait of the political oligarchy in this country. The power circle that is only filled with family and relatives is a major factor in corruption easily occurring.East Kalimantan Governor Isran Noor said he was surprised by the case of the East Kutai Regent (Kutim) Ismunandar and his wife Encek UR Firgasih who were caught in the KPK's arrest operation (OTT). Both were arrested in Jakarta on Thursday (2/7) night. They allegedly received gratuities for the project in East Kutai. Nearing midnight, the KPK also sealed nine rooms in four East Kutai Regency Government offices including the office of the Regent of Ismunandar.

Besides them, there were a number of other officials in Kutim who were also arrested by the KPK.Governor Isran reminded all officials in East Kalimantan not to carry out illegal actions. He hopes Ismunandar becomes the last regional head in his area who is entangled in a case. "Hopefully this case will last. It will never happen again. I am concerned,". Isran said Noor as governor of east Kalimantan. Before Ismunandar, there was a regional head in East Kalimantan who was arrested by the KPK with the same case, namely gratification. The case occurred three years ago which struck the Regent of Kutai Kartanegara Rita Widyasari in September 2017. Rita was sentenced to 10 years in prison.

This can be seen from the case that occurred in East Kutai. the regional head and his staff are caught in a corruption case. the pattern played cannot be separated from a gratification project with a family connection mechanism or commonly known as a political oligarchy mechanism among the bureaucratic elite. Political oligarchy poses a real threat to the existence of democracy at the local level. Also, being one of the determinants of the high inequality in some areas. Thus, it is important to counter the hegemony of political oligarchy, especially in relation to welcoming Regional Elections. Meaning On the other hand, democracy has slipped into the vortex of oligarchs. Oligarchy is only strong in conditions of a society that is weak economically and politically. Poverty and political political will are the key to success of the oligarchy. The oligarch politicians will continue to produce wealth and hegemony through procedural democracy. However, despite being very powerful, oligarchs have "defects" or weaknesses. Oligarchy will not grow and develop very strongly in a strong civil society. Because civil society understands the danger of oligarchy. I conclude this by concluding what Winter said that what is most needed for the oligarchic cycle to break and form a new social order is a comprehensive social and political revolution, both in the liberal and other paths.

\section{Variety of Corruption Mode throughout 2019}

Bribery is the most common mode in investigating corruption cases. There are at least 51 cases of corruption with bribery. The value of bribes is Rp. 169.5 billion while money laundering is $\mathrm{Rp} .46$ billion. The abuse of authority was 30 cases. The amount is not as much as a bribe, but the value of losses caused by the state reached Rp 6.3 trillion. Nominal at once the largest compared to other modes. Last year, there were at least 271 cases with a total state loss of Rp. 8.4 trillion. The number of suspects was 580 people with different backgrounds, ranging from state civil servants, the private sector, to officials of the State-Owned Enterprises (BUMN). 


Bribes
Mark up
Budget abuse
Embezzlement
Abuse of authority
Fictional activities/project
Fictional report
Illegal Levies
Gratuities
Extortion
Cutting
Markdown

Figure.5 Number of Cases Based on Corruption Mode in 2019

Source: Katadata.com, (2019).

Based on the data that shows figure.5 Explain that the number of corruption mode cases in 2019 was more in bribery cases, around 50 cases, the second position was marked up by around 40 cases and the third position was budget misuse, the fourth was embezzlement, the fifth was cases of abuse of authority. Six there are fictitious activities or projects, seven there are cases of fictitious reports, eight gratuities, etc. Cases like this are rife in the bureaucratic environment and the political elite. All of these problems are caused by weak supervision, which is due to the influence of the dominant position of the government bureaucracy as the main source of goods, services and employment and as a regulator of economic activity; and the dominance of countries that dwarf other powers in bureaucratic societies, especially in developing countries, tend to have a stronger position than other institutions, because the bureaucracy has an important source of power, especially the mastery of information and possession of technical expertise to manage the government so that community control is weak. On the other hand, a weak citizen will offer a bribe in the hope that he can change the behavior of the bureaucrats who keep their distance closer to him and become his 'patron', so that the citizen can get a privileged advantage in dealing with the government.

The number of corruption committed by the House of Representatives (DPR) and the Regional House of Representatives (DPRD) from 2004 to 2018 was 67 cases. In 2005 until 2007 there were no criminal acts of corruption. However, in 2016 the criminal act of corruption by the DPR and DPRD jumped to 15 cases.

Data problems from above are caused by individual factors namely the low level of morale and integrity of employees and key leaders. These individual factors are more suitable for Asian contexts than structural factors. If we pay attention, the Indonesian government is not a law and regulation that does not exist but factors that exist outside the structure of government. If corrupt people take control of any government structure, the structure will undoubtedly be reflected. Conversely, in any kind of structure, if the type of positive and moral ruling. Undoubtedly they will breed and maintain their power Cultural, structural and individual factors as explained above are the causes of corruption in many societies. But why are some countries able to withstand the pressure of corruption and some are not,

In addition, the phenomenon of recruiting leaders in Indonesia today experiences many problems. The problem of recruiting leaders is actually not the problem of those in which the businessman is not allowed to be a people's representative or a public leader, but competence and ability are important factors in leadership. Borrowing Bahctiar Aly,Never before in the history of independent Indonesia, the credibility of the nation's leaders and elites collapsed. Top leaders to the lowest level experience a crisis of confidence they lose their authority, their legitimacy is weakened. Legislative, executive and judicial officials should be responsible for their performance. Also shows an open attitude that is honest, fair. But that is only utopian, what is happening right now is the rampant actions that violate the ethics and morals of our 
leaders. The progress of an area is determined by the quality of competent human resources. Therefore, a clean and honest recruitment is needed in realizing good governance and far from corrupt behavior. Of all the problems above will have an adverse effect on the country including:

1. Damaging the public order system, norms of society that are damaged by conspiracy supported by the public.

2. The suffering of most people in the economic, administrative, political and legal sectors.

3. The destruction of the economy of a country that is caused directly or indirectly by corruption will result in suffering for most people.

\section{CONCLUSION}

Based on the above definition, it can be concluded that many factors cause corruption in government, namely Cultural Factors (Culture or patrimonial bureaucratic systems), Structural Factors (Supervision Systems and Special Supervision Systems), Individual Factors (low level of morality and integrity). Competent institutional supervision is also not optimal and the recruitment of corrupt leaders is a difficult factor in combating corruption in Indonesia. Efforts to promote corruption in Indonesia are still partial and do not have a clear strategic design so that in many cases they have not been able to reduce the level of corruption in government at the central and regional levels. This can be seen from the incident in East Kutai. Regional heads and officials caught in corruption cases. The pattern that is being played is inseparable from the satisfaction project through the family relationship mechanism or what is commonly referred to as the political oligarchy mechanism among the bureaucratic elite. Political oligarchy is a real threat to the democratic system at the local level. Besides, this is a determining factor for high inequality in several regions. Therefore, political oligarchic hegemony needs to be rejected, especially concerning elections. On the other hand, democracy is in the vortex of oligarchy. Oligarchy is only strong in societies that are weak economically and politically. Poverty and political will are the keys to the success of the oligarchy. Oligarch politicians will continue to generate wealth and hegemony through procedural democracy. However, although very strong, the oligarchs have "flaws" or weaknesses. The oligarchy will not grow and develop in a strong civil society. Because civil society knows the dangers of oligarchy. I conclude this by summarizing what winter said about what is most needed to end the cycle of oligarchy and create a new social order that is a comprehensive social and political revolution, on liberal and other lines.

\section{ACKNOWLEDGMENT}

As a researcher, I would like to thank the Mulawarman University institution for supporting this research. Hopefully, this research can make a big contribution to other researchers.

\section{REFERENCE}

Anggraeni, T. D. (2014). Menciptakan Sistem Pelayanan Publik yang Baik: Strategi Reformasi Birokrasi dalam Pemberantasan Korupsi. Rechts Vinding, 3(3), 417-433.

Aspinall, E. (2015). The Surprising Democratic Behemoth: Indonesia in Comparative Asian Perspective. The Journal of Asian Studies, 74(4), 889-902. https://doi.org/10.1017/S0021911815001138

Badjuri, A. (2011). Peranan Komisi Pemberantasan Korupsi (KPK) sebagai lembaga anti korupsi di indonesia. Jurnal Bisnis Dan Ekonomi (JBE), 18(Maret 2011), 84-96.

Baswir, R. (2002). Dinamika Korupsi di Indonesia dalam Perspektif Struktural. Jurnal Universitas Paramadina, 2(1), 25-34.

Ford, M., \& Pepinsky, T. B. (2014). Beyond Oligarchy: Wealth, Power and Contemporary Indonesian Politics. Cornell Southeast Asia Program Publications, 180, 4.

Hadiz, V. R. (2004). The rise of neo-Third Worldism? The Indonesian trajectory and the consolidation of illiberal democracy. Third World Quarterly, 25(1), 55-71. https://doi.org/10.1080/0143659042000185336

Lay, C. (2012). Democratic Transition in Local Indonesia: An Overview of Ten Years Democracy. Jurnal Ilmu Sosial Dan Ilmu Politik, 15, 13. 
Nugroho, H. (2013). Efektivitas Fungsi Koordinasi dan Supervisi dalam Penyidikan Tindak Pidana Korupsi oleh Komisi Pemberantasan Korupsi. Jurnal Dinamika Hukum Vol. 13 No. 3 September 2013, 13(3), 392-401.

Pratama, P. Y., Budiman, B., \& Sarmiasih, M. (2019). A Comparative Political Analysis Between The New Order Regime And The Reformed Era In Indonesia: A Case Study Of Oligarchy Politics In The Mining Industry Of East Kalimantan. Jurnal Studi Pemerintahan, 10(3), 194-207.

Rahman, F. (2011). Korupsi Di Tingkat Desa Pendahuluan Setiap negara pasti terdapat korupsi. Korupsi paling banyak dijumpai pusat. Tetapi kasus korupsi yang dilaporkan limabelas kali lipat dan jumlah empiris betapa perilaku korupsi semakin massif dan tak terkendali. 3 Te. Governance, 13-14.

Slater, D., \& Simmons, E. (2010). Informative Regress: Critical Antecedents in Comparative Politics. Comparative Political Studies, 43(7), 886-917. https://doi.org/10.1177/0010414010361343

Suherry, S. (2017). Politik Pemberantasan Korupsi di Indonesia. Otoritas: Jurnal Ilmu Pemerintahan, 7(1), 46. https://doi.org/10.26618/ojip.v7i1.417

Tahir, A., Bachri, S., Ruslan, A., \& Abdullah, F. (2015). The Local Election and Local Politic in Emboding the Democracy. 9.

Wakhid, A. A. (2011). Eksistensi Konsep Birokrasi Max Weber Dalam Reformasi Birokrasi di Indonesia. Jurnal Tapis, 7(13), 127-146.

Winters, J. A. (2013). Oligarchy and Democracy in Indonesia. Southeast Asia Program Publications at Cornell University, 96(Wealth, Power, and Contemporary Indonesian Politics), 11-33.

\section{Website:}

https://databoks.katadata.co.id/datapublish/2020/02/19/ragam-modus-korupsi-sepanjang2019

https://databoks.katadata.co.id/datapublish/2020/02/19/10-lembaga-dengan-temuan-kasuskorupsi-terbanyak

https://databoks.katadata.co.id/datapublish/2020/10/09/114-kepala-daerah-terjeratkorupsi-sejak-2004-2019

https://nasional.okezone.com/read/2020/07/05/337/2241363/kasus-korupsi-kutai-timurungkap-family-connection-antara-para-tersangka.

https://mediaindonesia.com/read/detail/325271-gubernur-isran-jangan-ada-lagi-kasus-ott-dikaltim

https://jatimtimes.com/baca/217872/20200703/081800/kpk-ott-di-kaltim-bupati-kutaitimur-ditangkap-hingga-rumah-disegel 